\title{
Use of phosphorus fertilization and mycorrhization as strategies for reducing copper toxicity in young grapevines
}

\author{
Gustavo Brunetto $^{\mathrm{a}}$, Daniel J. Rosa ${ }^{\mathrm{b}}$, Vítor G. Ambrosini ${ }^{\mathrm{c}}$, Janaina Heinzen ${ }^{\mathrm{b}}$, Paulo A.A. Ferreira ${ }^{\mathrm{a}}$, \\ Carlos A. Ceretta ${ }^{a}$, Cláudio R.F.S. Soares ${ }^{\mathrm{b}}$, George W.B. Melo ${ }^{\mathrm{d}}$, Hilda H. Soriani ${ }^{\mathrm{e}}$, \\ Fernando T. Nicoloso ${ }^{\mathrm{f}}$, Júlia G. Farias ${ }^{\mathrm{f}}$, Lessandro De Conti ${ }^{\mathrm{g}}$, Lincon O.S. Silva ${ }^{\mathrm{a}}$, Natielo Santana ${ }^{\mathrm{a}}$, \\ Rafael R. Couto ${ }^{\mathrm{b}}$, Rodrigo J.S. Jacques ${ }^{\mathrm{a}}$, Tadeu L. Tiecher ${ }^{\mathrm{g}, *}$
}

${ }^{a}$ Soil Science Department of Federal University of Santa Maria (UFSM), 97105-900, Santa Maria, RS, Brazil

${ }^{\mathrm{b}}$ Centre for Biological Sciences, Department of Microbiology, Immunology and Parasitology, Federal University of Santa Catarina, Florianopolis, SC, Brazil

${ }^{\mathrm{c}}$ Soil Science Department of Federal University of Rio Grande do Sul (UFRGS), 91540-000, Porto Alegre, RS, Brazil

${ }^{\mathrm{d}}$ National Research Center of Grape and Wine, Brazilian Agricultural Research Corporation (Embrapa), 95700-000, Bento Gonçalves, RS, Brazil

${ }^{\mathrm{e}}$ Forestry Department, Federal University of Santa Maria, Campus Frederico Westphalen, 98400-000, Frederico Westphalen, RS, Brazil

${ }^{\mathrm{f}}$ Biology Department, Center of Natural and Exact Sciences, Federal University of Santa Maria (RS), 97105-900 Santa Maria, RS, Brazil

${ }^{\mathrm{g}}$ Federal Institute Farroupilha, Campus Alegrete, 97555-000, Alegrete, RS, Brazil

\section{A R T I C L E I N F O}

\section{Keywords:}

Arbuscular mycorrhizal fungi

Rhizophagus clarus

Vitis labrusca L

Heavy metals

\begin{abstract}
A B S T R A C T
Established vineyard soils may have high copper $(\mathrm{Cu})$ contents due to the ongoing foliar applications of copperbased fungicides. In viticulture, the replacement of old vineyards with new vines is common practice, however, limited by $\mathrm{Cu}$ excess in soil and its toxicity to young grapevines. The application of phosphorus (P) and arbuscular mycorrhizal fungi (AMF) inoculation are potential strategies to reduce Cu toxicity to young grapevines. This study aimed to assess the effects of phosphorus fertilization and AMF (Rhizophagus clarus) inoculation on growth and physiological parameters of young grapevines grown in soil with high Cu content. The experiment was conducted in a greenhouse, where natural grassland soil was artificially contaminated by the addition of $60 \mathrm{mg} \mathrm{kg}^{-1} \mathrm{Cu}$. The soils were treated with and without AMF inoculation, combined with additions of 0,40 and $100 \mathrm{mg} \mathrm{P} \mathrm{kg}{ }^{-1}$. After 90 days of cultivation, grapevine plants were assessed for chlorophyll $a$ fluorescence, photosynthetic pigment contents, superoxide dismutase (SOD) activity, plant height, plant biomass, and concentrations of $\mathrm{Cu}$ and $\mathrm{P}$ in roots and shoots. Phosphorus fertilization promoted increases in seedling growth (related to the increase of total P concentration in roots and shoots), soluble Pi concentration in leaves, and the quantum yield of the PSII (YII) (associated with a reduction in shoot Cu concentration). The AMF inoculation increased the concentration of $\mathrm{P}$ in roots and shoots, soluble $\mathrm{Pi}$ in leaves and electron transport rate (ETR). Phosphorus fertilization and inoculation of grapevines with AMF are strategies capable of reducing Cu toxicity in young grapevines.
\end{abstract}

\section{Introduction}

The application of copper fungicides such as the Bordeaux mixture $\left[\mathrm{CuSO}_{4}+\mathrm{Ca}\left(\mathrm{OH}_{2}\right)\right]$ is a common phytosanitary practice in fruit production and aims to prevent foliar fungal diseases. In grape production, successive applications of Bordeaux mixture are carried out throughout the crop production cycle, contributing to the production of high yields and grapes with adequate composition for the production of wines, juices and sparkling wines. However, most of the fungicide ends up in soil due to runoff during application, rainfall or leaf senescence.
Throughout the years of cultivation, a considerable increase in $\mathrm{Cu}$ content is observed in soils of vineyards that use the Bordeaux mixture (Brunetto et al., 2016; Tiecher et al., 2017, 2018). When the old vineyards are eradicated, the soil is plowed, and young grapevines are transplanted. However, excess of $\mathrm{Cu}$ in soil may cause toxicity to young grapevines, negatively effecting the new vineyard establishment.

$\mathrm{Cu}$ is essential for plant growth and development, working as a cofactor in enzymes such as Cu-Zn superoxide dismutase (SOD), cytochrome oxidase, amino oxidase, plastocyanin and polyphenol oxidase (Yruela, 2005). Conversely, high Cu concentrations in plant tissue may

\footnotetext{
* Corresponding author.

E-mail address: tadeu.t@hotmail.com (T.L. Tiecher).
} 
cause toxicity, effecting membrane transporters and ion channels (Janicka-Russak et al., 2008), increasing non-specific membrane permeability thus resulting in nutritional imbalances (Ferreira et al., 2015). Furthermore, Cu may cause damage to the plant photosynthetic apparatus (Cambrollé et al., 2015; Tiecher et al., 2018) and cause oxidative stress by generating imbalance between antioxidant responses and increased production of reactive oxygen species (ROS) (Girotto et al., 2013).

Establishing management strategies to reduce $\mathrm{Cu}$ availability and toxicity have become crucial for grapevines production in Cu-contaminated soils. Among these strategies the application of phosphorus (P) through pre-planting fertilization contributes for the insoluble $\mathrm{Cu}$ phosphate formation (Cao et al., 2003) and the phosphate anion can bind to the surface of reactive soil particles such as oxides (Barrow, 1999; Pérez-Novo et al., 2009). This allows the formation of oxidephosphate-metal type complexes (McBride, 1994), also resulting in insoluble compounds with $\mathrm{Cu}$ in roots, which reduces transport to shoot organs (Ferreira et al., 2015), which are more sensitive to excess $\mathrm{Cu}$.

An alternative strategy to reduce $\mathrm{Cu}$ toxicity is the inoculation of grapevines with arbuscular mycorrhizal fungi (AMF) (Ambrosini et al., 2015; Rosa et al., 2016; Ferreira et al., 2018). The establishment of this symbiosis can exert a phytoprotective effect in soils with high $\mathrm{Cu}$ content. These fungi can reduce $\mathrm{Cu}$ uptake by precipitation or chelation in rhizosphere (Cabral et al., 2015). AMF can also retain and immobilize heavy metals in fungal structures (Cornejo et al., 2013; Cabral et al., 2015) and reduce translocation to shoots (Ambrosini et al., 2015; Rosa et al., 2016). However, the positive effects of AMF in plant protection vary according to the fungal isolate, heavy metal and plant species (Meyer et al., 2016), and may be affected by P availability in soil (Cabral et al., 2015).

Although the application of $\mathrm{P}$ in soil and the use of AMF show great potential in reducing $\mathrm{Cu}$ toxicity in cultivated plants, few studies have combined these strategies for the phytoprotection of young grapevines grown in Cu-contaminated vineyards. This study aimed to assess the effects of phosphorus fertilization and AMF (Rhizophagus clarus) inoculation on growth and physiological changes of young grapevines grown in soil with high $\mathrm{Cu}$ content.

\section{Materials and methods}

\subsection{Soil}

The soil used was a Typic Hapludalf (Soil Survey Staff, 2006) of a non-anthropic natural grassland area $\left(30^{\circ} 47^{\prime} 23.5^{\prime \prime} \mathrm{S}\right.$ and $\left.55^{\circ} 22^{\prime \prime} 7.0^{\prime \prime} \mathrm{W}\right)$ adjacent to a vineyard of the Campanha Gaúcha region, located in the city of Santana do Livramento (RS), southern Brazil. The soil was collected at a depth of $0.00-0.20 \mathrm{~m}$, air-dried, ground, passed through a $4 \mathrm{~mm}$ mesh sieve and subjected to the application of calcium carbonate $\left(\mathrm{CaCO}_{3}\right)$ and magnesium oxide $(\mathrm{MgO})$ in $2: 1 \mathrm{Ca}: \mathrm{Mg}$ ratio to bring the $\mathrm{pH}$ up to 6.0. The soil was then placed in plastic bags and distilled water was added to raise the soil moisture to $70 \%$ of the maximum water holding capacity (MWHC). The soil was incubated for 45 days. The bags were opened daily to remove $\mathrm{CO}_{2}$, and then homogenized, weighed and distilled water was added when necessary to maintain MWHC at 70\%.

Afterwards, the soil was air-dried, ground and fertilized with 0, 40 and $100 \mathrm{mg} \mathrm{P} \mathrm{kg}^{-1}$ using triple superphosphate. Then, the three portions of soil were incubated for 45 days, as described previously. At the end of this period, the soil was air-dried, ground and contaminated with $60 \mathrm{mg} \mathrm{kg}^{-1}$ using solution of $\mathrm{CuSO}_{4} \cdot 5 \mathrm{H}_{2} \mathrm{O}$, and incubated again for 45 days. After incubation, the soil was sterilized by autoclaving at $121{ }^{\circ} \mathrm{C}$ for two hours and placed into $5 \mathrm{~kg}$ pots containing $4.5 \mathrm{~kg}$ of soil. The main chemical characteristics of the soil after preparation are shown in Table 1.
Table 1

Soil chemical and physical characterization after the application of $\mathrm{Cu}$ and $\mathrm{P}$ (Ferreira et al., 2015).

\begin{tabular}{|c|c|c|c|}
\hline Soil characteristics & $\begin{array}{l}0 \mathrm{mg} \mathrm{kg}^{-1} \\
\mathrm{P}\end{array}$ & $\begin{array}{l}40 \mathrm{mg} \mathrm{kg}^{-1} \\
\mathrm{P}\end{array}$ & $100 \mathrm{mg} \mathrm{kg}^{-1} \mathrm{P}$ \\
\hline $\mathrm{pH}\left(\mathrm{H}_{2} \mathrm{O}\right)$ & 5.9 & 5.6 & 5.5 \\
\hline TOC $\left(\mathrm{g} \mathrm{kg}^{-1}\right)$ & 6.5 & 6.5 & 6.5 \\
\hline Available $\mathrm{Cu}$ by EDTA $\left(\mathrm{mg} \mathrm{kg}^{-1}\right)$ & 45.6 & 45.5 & 42.5 \\
\hline $\mathrm{Cu}^{2+}$ in soil solution $\left(\mathrm{mg} \mathrm{L}^{-1}\right)$ & 10.5 & 7.3 & 4.8 \\
\hline $\begin{array}{l}\text { Available P by Mehlich-1 (mg } \\
\mathrm{kg}^{-1} \text { ) }\end{array}$ & 5.6 & 34.1 & 85.3 \\
\hline $\mathrm{PO}_{4}{ }^{3-}$ in soil solution $\left(\mathrm{mg} \mathrm{L}^{-1}\right)$ & 5.2 & 7.4 & 10.1 \\
\hline $\begin{array}{l}\text { Available K by Mehlich-1 (mg } \\
\qquad \mathrm{kg}^{-1} \text { ) }\end{array}$ & 190.5 & 183.5 & 170.5 \\
\hline Exchangeable $\mathrm{Ca}\left(\mathrm{mg} \mathrm{kg}^{-1}\right)$ & 458.4 & 458.4 & 552.8 \\
\hline Exchangeable $\mathrm{Mg}\left(\mathrm{mg} \mathrm{kg}^{-1}\right)$ & 90.7 & 94.1 & 94.4 \\
\hline Clay $\left(\mathrm{g} \mathrm{kg}^{-1}\right)$ & 54 & 54 & 54 \\
\hline Sand $\left(\mathrm{g} \mathrm{kg}^{-1}\right)$ & 894 & 894 & 894 \\
\hline Silt $\left(\mathrm{g} \mathrm{kg}^{-1}\right)$ & 52 & 52 & 52 \\
\hline
\end{tabular}

Table 2

$\mathrm{F}$ values and coefficients of variation of the variables analyzed in young grapevines grown in soil with high $\mathrm{Cu}$ content subjected to $\mathrm{P}$ applied, with and without inoculation with $R$. clarus.

\begin{tabular}{|c|c|c|c|c|}
\hline \multirow[t]{2}{*}{ Variable } & \multicolumn{3}{|l|}{$\mathrm{F}$ values } & \multirow[t]{2}{*}{ CV (\%) } \\
\hline & $\begin{array}{l}\text { AMF inoculation } \\
\text { (A) }\end{array}$ & $\mathrm{P}$ doses (B) & $\mathrm{A} \times \mathrm{B}$ & \\
\hline Plant height $(\mathrm{cm})$ & $0.36^{\mathrm{ns}}$ & $7.76^{* *}$ & $2.82^{\mathrm{ns}}$ & 12.06 \\
\hline Number of leaves & $10.11^{* *}$ & $4.66^{*}$ & $0.53^{\mathrm{ns}}$ & 10.15 \\
\hline Root dry matter (g) & $0.02^{\mathrm{ns}}$ & $5.32^{*}$ & $1.52^{\mathrm{ns}}$ & 18.72 \\
\hline Shoot dry matter (g) & $1.02^{\mathrm{ns}}$ & $5.73^{*}$ & $2.59^{\mathrm{ns}}$ & 15.65 \\
\hline Root $\mathrm{P}\left(\mathrm{g} \mathrm{kg}_{-}{ }^{1}\right)$ & $18.95^{* *}$ & $88.35^{* *}$ & $2.71^{\mathrm{ns}}$ & 9.09 \\
\hline Shoot $\mathrm{P}\left(\mathrm{g} \mathrm{kg}^{-1}\right)$ & $6.32^{*}$ & $7.01 * *$ & $1.01^{\mathrm{ns}}$ & 11.16 \\
\hline Root $\mathrm{Cu}\left(\mathrm{mg} \mathrm{kg}^{-1}\right)$ & $7.12^{*}$ & $1.31^{\mathrm{ns}}$ & $9.09^{* *}$ & 27.86 \\
\hline Shoot $\mathrm{Cu}\left(\mathrm{mg} \mathrm{kg}^{-1}\right)$ & $0.14^{\mathrm{ns}}$ & $5.38^{*}$ & $3.17^{\mathrm{ns}}$ & 17.15 \\
\hline Chlorophyll $a\left(\mathrm{mg} \mathrm{g} \mathrm{FM}^{-1}\right)$ & $0.18^{\mathrm{ns}}$ & $0.43^{\mathrm{ns}}$ & $0.44^{\mathrm{ns}}$ & 13.67 \\
\hline Chlorophyll $b\left(\mathrm{mg} \mathrm{g} \mathrm{FM}^{-1}\right)$ & $2.43^{\mathrm{ns}}$ & $4.33^{*}$ & $1.11^{\mathrm{ns}}$ & 17.40 \\
\hline $\begin{array}{l}\text { Total chlorophyll (mg g } \\
\mathrm{FM}^{-1} \text { ) }\end{array}$ & $0.80^{\mathrm{ns}}$ & $0.96^{\mathrm{ns}}$ & $0.61^{\mathrm{ns}}$ & 14.18 \\
\hline Carotenoids (mg g FM ${ }^{-1}$ ) & $1.25^{\mathrm{ns}}$ & $2.08^{\mathrm{ns}}$ & $0.25^{\mathrm{ns}}$ & 11.10 \\
\hline $\mathrm{Fv} / \mathrm{Fm}$ & $1.57^{\mathrm{ns}}$ & $0.56^{\mathrm{ns}}$ & $0.86^{\mathrm{ns}}$ & 2.73 \\
\hline ETR & $5.77^{*}$ & $1.83^{\mathrm{ns}}$ & $1.12^{\mathrm{ns}}$ & 9.58 \\
\hline $\mathrm{Y}(\mathrm{II})$ & $4.68^{\mathrm{ns}}$ & $16.68^{* *}$ & $1.31^{\mathrm{ns}}$ & 5.49 \\
\hline Leaf inorganic $\mathrm{P}\left(\mathrm{mg} \mathrm{kg}^{-1}\right)$ & $11.01 * *$ & $51.75^{* *}$ & $1.37^{\mathrm{ns}}$ & 16.80 \\
\hline SOD (U mg protein $\left.{ }^{-1}\right)$ & $0.0005^{*}$ & $4.26^{*}$ & $1.42^{\mathrm{ns}}$ & 14.92 \\
\hline
\end{tabular}

$*$ = Significant by the $\mathrm{F}$ test $(\mathrm{p}<0.05) ; * *=$ Significant by the $\mathrm{F}$ test $(\mathrm{p}<0.01) ; \mathrm{ns}=$ not significant.

\subsection{Conduction of the experiment}

The experiment was established in a $2 \times 3$ factorial design, with and without AMF inoculation and three doses of $\mathrm{P}(0,40$ and $100 \mathrm{mg} \mathrm{P}$ $\mathrm{kg}^{-1}$ ), with 4 replicates per treatment. Treatments containing AMF were inoculated with Rhizophagus clarus isolate (T.H. Nicolson; N.C. Schenck), UFSC-14 isolate, supplied by the Soil Microbiology Laboratory of the Universidade Federal de Santa Catarina (UFSC), located in the city of Florianópolis, state of Santa Catarina, Brazil. Plant inoculation was carried out by applying 100 spores of $R$. clarus directly on the roots of the grape seedlings at the time of transplanting. Spores were obtained by wet sieving (Gerdemann and Nicolson, 1963), followed by centrifugation in water at $2000 \mathrm{rpm}$ for three minutes and in sucrose $(45 \% \mathrm{w} / \mathrm{v})$ at $1500 \mathrm{rpm}$ for two minutes. The spores were counted using a stereoscopic microscope (40x). In non-inoculated treatments, $50 \mathrm{~mL}$ of a filtrate of soil inoculum without AMF propagules was added, aiming to restore soil microbiota. Afterwards, 100, 30, 5.0 and $0.81 \mathrm{mg} \mathrm{kg}^{-1}$ of $\mathrm{N}\left(\mathrm{NH}_{4} \mathrm{Cl}\right), \mathrm{K}\left(\mathrm{K}_{2} \mathrm{SO}_{4}\right), \mathrm{Zn}\left(\mathrm{ZnSO}_{4} \cdot 7 \mathrm{H}_{2} \mathrm{O}\right)$ and $\mathrm{B}$ $\left(\mathrm{H}_{3} \mathrm{BO}_{3}\right)$ were added in each pot, respectively. The grapevines used were of the Niagara Rosada cultivar (Vitis labrusca L.). One plant was 

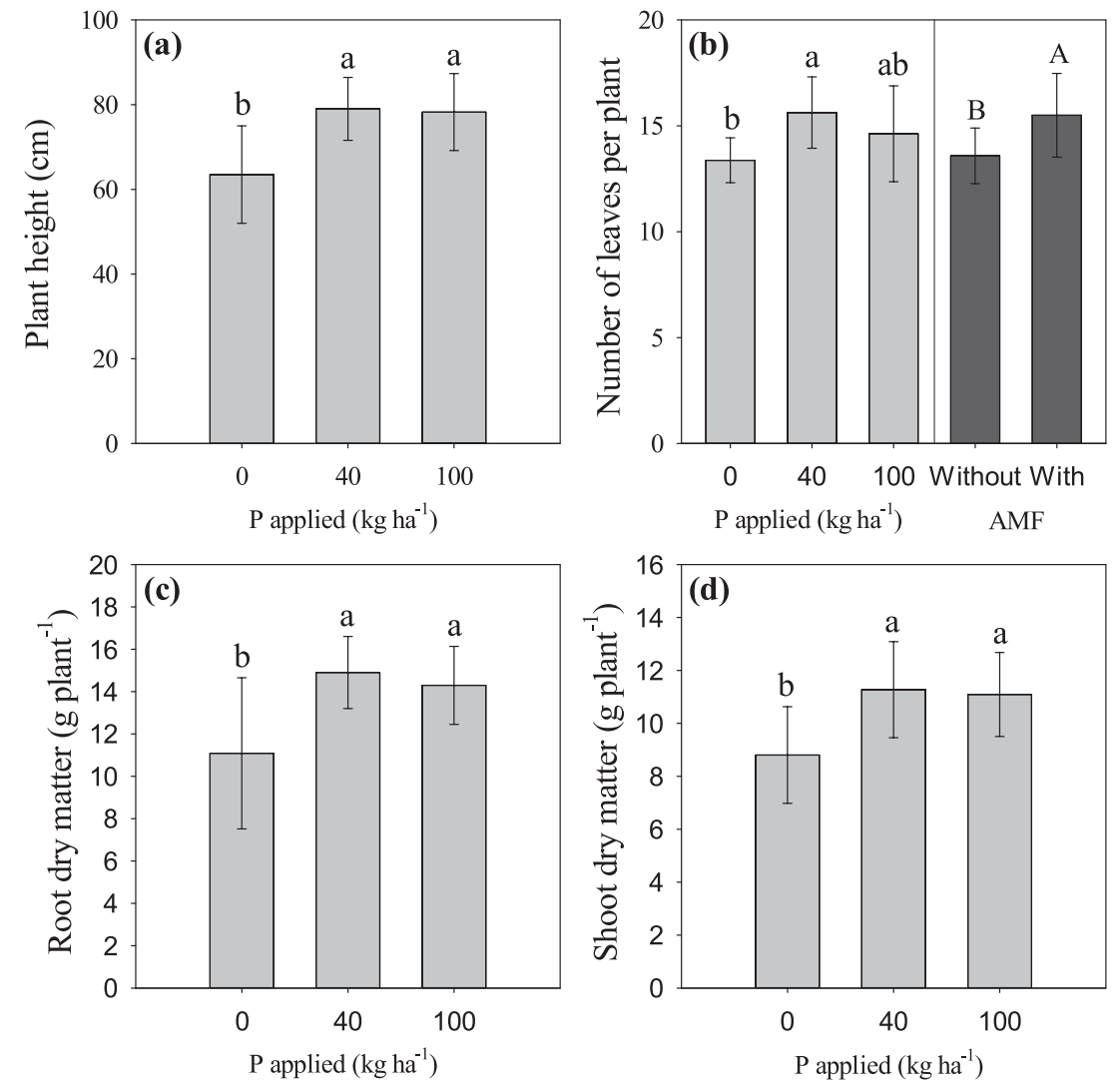

Fig. 1. Plant height (a), number of leaves (b), root (c) and shoot (d) dry matter in young grapevines grown in soil with high $\mathrm{Cu}$ content subjected to $\mathrm{P}$ applied, with and without inoculation with $R$. clarus. The vertical bars in each column represent the standard deviation of the mean. Same uppercase letters compare treatments with and without inoculation with $R$. clarus, and lowercase letters compare $\mathrm{P}$ applied. Means followed by the same letters do not differ the treatments by the Tukey test $(\mathrm{p}<0.05)$. ns $=$ not significant. transplanted into each pot containing the treated soils. The cultivation was done in a greenhouse with air temperature of $25 \pm 5{ }^{\circ} \mathrm{C}$ and relative humidity of $70 \%$. At 15 and 30 days after the transplanting (DAT) of the seedlings, $\mathrm{N}$ (urea) was applied at a dose of $100 \mathrm{mg} \mathrm{N} \mathrm{kg}^{-1}$ of soil.

\subsection{Plant growth and mycorrhizal colonization}

At 90 DAT, number of leaves per plant and plant height were determined. The shoots were cut close to the soil surface and a leaf sample was immediately placed in liquid $\mathrm{N}_{2}$ and stored at $-80^{\circ} \mathrm{C}$ until the time of the biochemical analysis. The roots were separated from the soil by hand and washed with $0.02 \mathrm{~mol} \mathrm{~L}^{-1}$ EDTA to remove chemical elements present on the root surface. To evaluate root colonization, approximately $2.0 \mathrm{~g}$ of roots were subjected to clearing and staining with trypan blue (Koske and Gemma, 1989) and the percentage of mycorrhizal colonization was determined by the intersections method in reticulated Petri dishes (Giovannetti and Mosse, 1980). The remainder of the shoots and roots were weighed on a precision scale to gauge dry matter yield. Then, shoots and roots were dried in an oven with forced air at $65^{\circ} \mathrm{C}$ until constant weight.

\subsection{Nutrient uptake}

Dry shoot and root samples were ground in a Wiley type mill and subjected to nitric-perchloric digestion (Sarruge and Haag, 1974). The total concentrations of $\mathrm{P}$ and $\mathrm{Cu}$ in shoot and roots were determined in inductively coupled plasma-optical emission spectroscopy (ICP-OES, Perkin-Elmer Optima 7000 DV, USA). The analysis of inorganic P (Pi) was done by centrifuging a portion of each fresh leaf sample at $43,200 \mathrm{~g}$ for $30 \mathrm{~min}$ at $4{ }^{\circ} \mathrm{C}$, according to the methodology described by Tabaldi et al. (2007). Subsequently, Pi was determined in leaf supernatant at $630 \mathrm{~nm}$, using malachite green as a colorimetric reagent and $\mathrm{KH}_{2} \mathrm{PO}_{4}$ as the standard for the calibration curve, according to Chan et al. (1986).

\subsection{Biochemical and physiological analysis}

At 60 DAT, chlorophyll $a$ fluorescence was measured using a JUNIOR-PAM fluorometer (Walz, Germany) Fluorescence reading was performed in three replicates of each treatment, between $3 \mathrm{a} . \mathrm{m}$. and 5 a.m. (without solar radiation). Initial fluorescence (Fo), maximum fluorescence (Fm), maximum quantum yield of PSII (Fv/Fm), electron transport rate (ETR) and effective quantum yield of PSII (Y(II)) were determined according Tiecher et al. (2018).

At 90 DAT, chlorophyll $a$ ( $\mathrm{Chl}$ a), chlorophyll $b(\mathrm{Chl} \mathrm{b)} \mathrm{and} \mathrm{car-}$ otenoid (Carot.) contents were determined according to the methodology described by Hendry and Grime (1993), and were calculated according to Lichtenthaler (1987). Samples of leaf tissue were collected for enzymatic analysis. The crude enzyme extract was obtained according Azevedo et al. (1998). The protein total concentration was determined according by Bradford (1976), and SOD (EC 1.15.1.1) activity was determined according the method described by Giannopolitis and Ries (1977). The detailed description of photosynthetic pigments and SOD activity methodology was available in Tiecher et al. (2018).

\subsection{Statistical analysis}

The data were submitted to Cochran's C test to check homoscedasticity. Afterwards, analysis of variance was performed and, when there was significance, the Tukey test $(\mathrm{p}<0.05)$ was applied. The variables were analyzed together with their respective $\mathrm{F}$ values and coefficients of variation in young grapevines grown in soil with high $\mathrm{Cu}$ content subjected to the application of P doses, with and without inoculation with $R$. clarus (Table 2). 

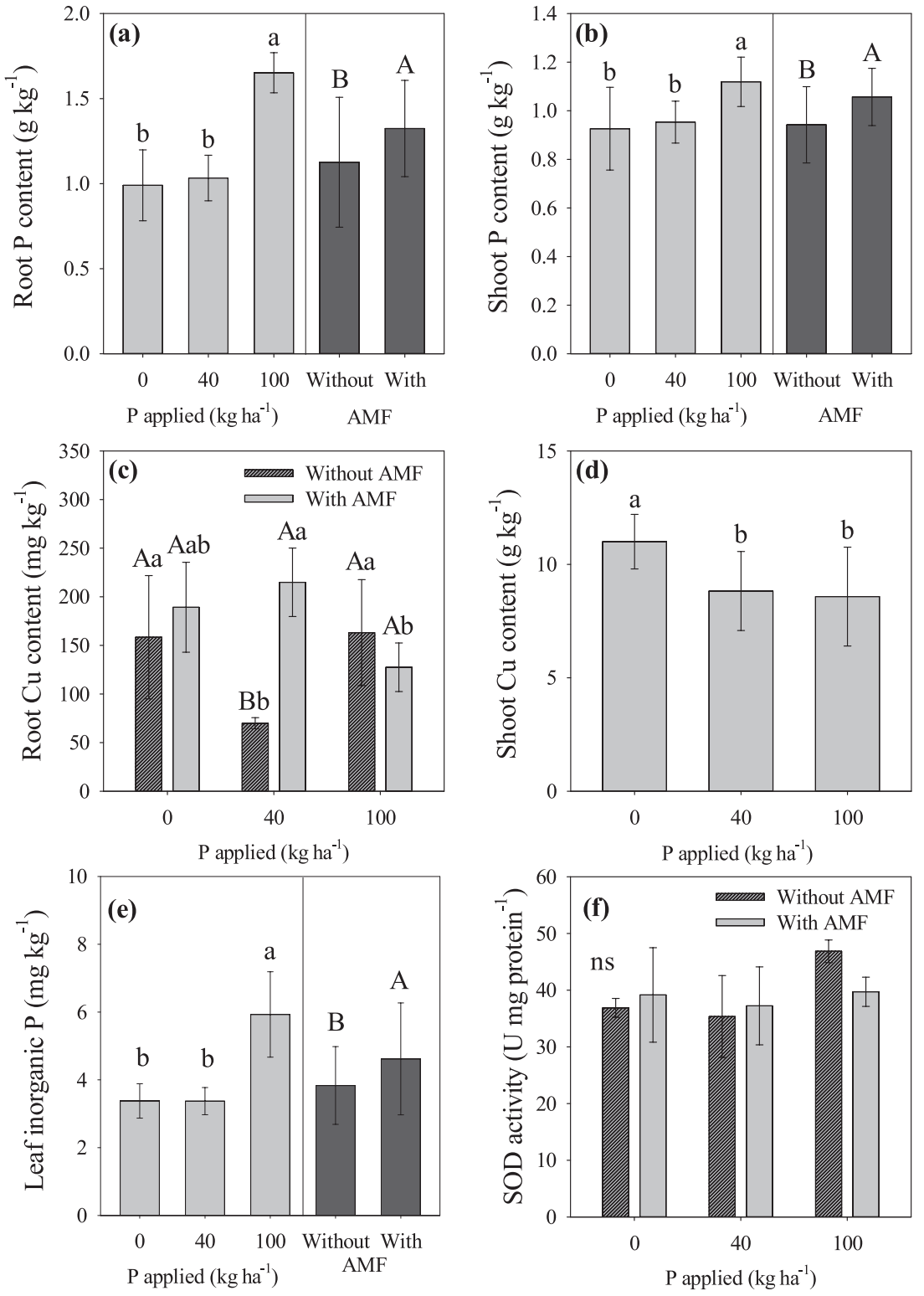

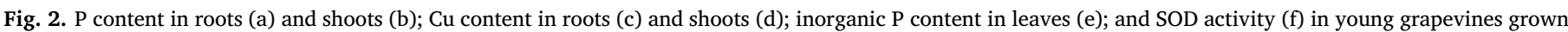

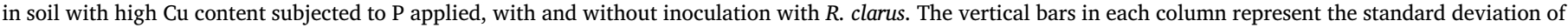

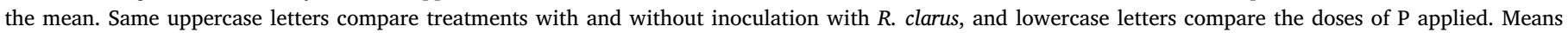
followed by the same letters do not differ the treatments by the Tukey test $(\mathrm{p}<0.05)$. ns $=$ not significant.

\section{Results}

\subsection{Growth and mycorrhizal colonization of young grapevines}

The increased in soil $\mathrm{P}$ levels stimulated plant growth, resulting in higher plants $(\mathrm{H})$, with more leaves per plant $(\mathrm{NL})$, bigger root system (RDM) and total shoot dry matter (SDM) (Table 2). These changes were observed between the control ( $0 \mathrm{P}$ added) and both tested doses ( 40 and $100 \mathrm{mg} \mathrm{P} \mathrm{k}^{-1}$ ), and with no statistical differences for these parameters between the doses (Fig. $1 \mathrm{a}, \mathrm{c}, \mathrm{d}$ ). The inoculation with $R$. clarus have only positively effected NL at a dose of $40 \mathrm{mg} \mathrm{P} \mathrm{kg}^{-1}$ (Fig. 1b and Table 2).

As expected, non-inoculated plants did not exhibit mycorrhizal colonization. In our study, mycorrhizal colonization in inoculated plants was not influenced by $\mathrm{P}$ concentrations applied to the soil. Mean colonization percentage of $42 \%$ was found (data not shown).

\subsection{Contents of total $P$, total $\mathrm{Cu}$ and inorganic $P$ in plant tissues}

The application of $100 \mathrm{mg} \mathrm{P} \mathrm{kg}^{-1}$ in soil resulted in root total $\mathrm{P}$ content increment of 67 and $60 \%$ as compared to 0 and $40 \mathrm{mg} \mathrm{P} \mathrm{kg}^{-1}$, respectively (Fig. 2a). Thus shoot total $\mathrm{P}$ content increased by 20 and $18 \%$ as compared to 0 and $40 \mathrm{mg} \mathrm{P} \mathrm{kg}^{-1}$, respectively. The inoculation of the grapevines increased total $\mathrm{P}$ content, on average, by $17 \%$ in roots and $12 \%$ in shoots (Fig. 2a and b).

Root $\mathrm{Cu}$ content was influenced by the interaction between $\mathrm{P}$ levels in soil and AMF inoculation (Table 2). In the treatments 0 and $100 \mathrm{mg} \mathrm{P}$ $\mathrm{kg}^{-1}$, AMF inoculation did not change root Cu contents. However, in the $40 \mathrm{mg} \mathrm{P} \mathrm{kg}^{-1}$ treatment, inoculation increased root $\mathrm{Cu}$ content by $207 \%$ (Fig. 2c). The application of $\mathrm{P}$ in soil reduced shoot $\mathrm{Cu}$ content (Fig. 2d). The content of leaf soluble Pi increased by $75 \%$ with the application of $100 \mathrm{mg} \mathrm{P} \mathrm{kg}^{-1}$ in comparison to the other $\mathrm{P}$ doses, while AMF inoculation increased it by $20 \%$ (Fig. 2e). 

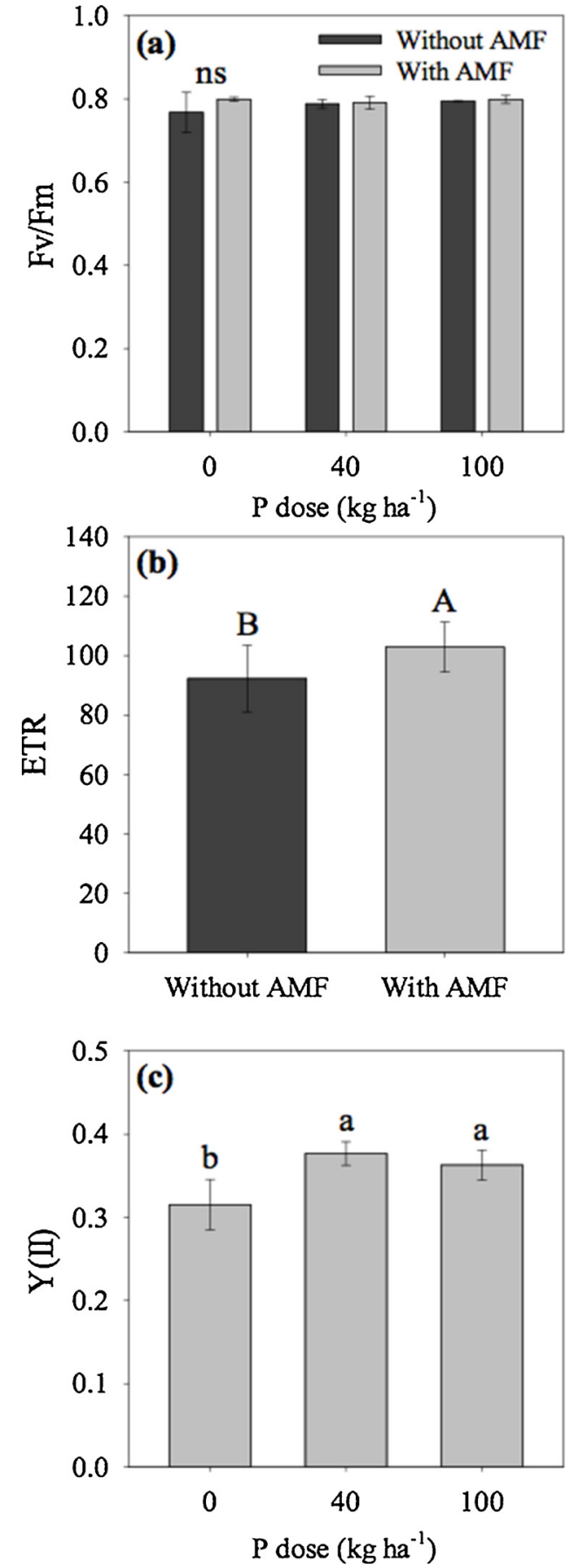

Fig. 3. Fluorescence parameters - maximum quantum yield (Fv/Fm) (a), electron transport rate (ETR) (b), and maximum quantum yield of PSII (Y(II)) (c) in leaves of young grapevines grown in soil with high $\mathrm{Cu}$ content subjected to $\mathrm{P}$ applied, with and without inoculation with $R$. clarus. The vertical bars in each column represent the standard deviation of the mean. Same uppercase letters compare treatments with and without inoculation with $R$. clarus, and lowercase letters compare P applied. Means followed by the same letters do not differ the treatments by the Tukey test $(\mathrm{p}<0.05)$. ns $=$ not significant.

\subsection{Chlorophyll a fluorescence}

The application of $\mathrm{P}$ and inoculation with $R$. clarus did not affect the maximum quantum yield of PSII (Fv/Fm) (Table 2). Electron transport rate (ETR) was $11 \%$ higher in leaves of inoculated plants (Fig. $3 \mathrm{~b}$ ) and was not influenced by $\mathrm{P}$ doses. The application of 40 and $100 \mathrm{mg} \mathrm{P} \mathrm{kg}^{-1}$ increased the quantum yield (YII) in leaves, compared to non-treated plants.

\subsection{Photosynthetic pigments and superoxide dismutase activity}

Chlorophyll $b$ concentration was 34 and $18 \%$ higher with the application of $100 \mathrm{mg} \mathrm{P} \mathrm{kg}^{-1}$ compared to 0 and $40 \mathrm{mg} \mathrm{P} \mathrm{kg}^{-1}$, respectively (Fig. 4b). The application of $\mathrm{P}$ and inoculation with $R$. clarus did not affect the concentrations of chlorophyll $a$, total chlorophyll, carotenoids and SOD activity in leaves (Figs. 4a, c, d, 2 f).

\section{Discussion}

Fertilization with 40 and $100 \mathrm{mg} \mathrm{P} \mathrm{kg}^{-1}$ resulted in increased $\mathrm{P}$ concentration available in soil to 34.1 and $85.3 \mathrm{mg} \mathrm{P} \mathrm{kg}^{-1}$, respectively (Table 1). This increased availability of $\mathrm{P}$ to grapevines improved plant nutritional status, thus increasing growth in soil artificially contaminated with $\mathrm{Cu}$. This strategy is essential in soils with low natural fertility, such as the one used in this study in which soil P content was considered very low $\left(5.6 \mathrm{mg} \mathrm{P} \mathrm{kg}^{-1}\right.$ in soil with $65 \mathrm{~g} \mathrm{~kg}^{-1}$ of clay, according to CQFS-RS/SC, 2016). Thus, P supply, which is an essential constituent of the cells, actively participating in photosynthesis, respiration, energy storage, and cell elongation and division (Gupta et al., 2014); and further $\mathrm{P}$ uptake may promote reduction of $\mathrm{Cu}$ translocation by inducing $\mathrm{Cu}$ retention in roots through copper-phosphate bonds (Cabral et al., 2015). Therefore, toxicity caused by excess $\mathrm{Cu}$ is decreased.

One of the features observed under $P$ fertilization is the capacity of plants to maintain lower $\mathrm{Cu}$ concentration in more sensitive photosynthetic organs (shoots), while storing most excess $\mathrm{Cu}$ in less sensitive organs (roots) (Yang et al., 2011; Farias et al., 2013; Ambrosini et al., 2015), contributing to greater plant growth. Additionally, due to the low natural fertility of our control soil, it may had generated nutritional deficiency in treatments without $\mathrm{P}$ addition, resulting in reduced plant growth. This is a common feature in Hapludalf soils of the Campanha Gaúcha region (soil used in this study) which naturally present low $\mathrm{P}$ contents (Brunetto et al., 2013; Farias et al., 2013).

The increase on $\mathrm{P}$ available in the soil also resulted in a higher $\mathrm{P}$ concentration in plant organs. Typical $\mathrm{P}$ concentrations in leaves of grapevines range from 1.2 to $4.0 \mathrm{~g} \mathrm{~kg}^{-1}$ (CQFS/RS-SC, 2016). Conversely, only the grapevines subjected to $100 \mathrm{mg} \mathrm{P} \mathrm{kg}^{-1}$ and/or inoculated with AMF had tissue $\mathrm{P}$ concentration in this range. This shows AMF efficiency in supplying $P$ to grapevines similarly to $P$ fertilization. These results agree with those of Ferreira et al. (2015) in a study with Crotalaria juncea grown in soil with excess $\mathrm{Cu}$, using the application of $\mathrm{P}$ doses and AMF inoculation as phytoremediation strategies. Besides that, high fertilizer inputs (especially P) are known to reduce AMF root colonization and propagules in many agrosystems, including vineyards. This effect depends on the rootstock and P sources in soil (calcium bisdihydrogen phosphate, tri-calcium phosphate, aluminum phosphate, and iron phosphate) (Trouvelot et al., 2015). Interestingly, in our study, mycorrhizal colonization in inoculated plants was not influenced by $\mathrm{P}$ concentrations applied to the soil.

This study also showed that inoculation with $R$. clarus is a promising strategy to reduce $\mathrm{Cu}$ toxicity in young grapevines. The $R$. clarus high colonization in grapevines promoted increased root and shoot $\mathrm{P}$ concentration, allowing the formation of a large number of hyphae that explore a greater volume of soil (Cabral et al., 2015). This potentiates the amount of nutrients absorbed by plants, especially P (Ambrosini et al., 2015). Therefore, the benefits provided by inoculation may be related to improved plant nutritional status.

The highest concentration of Pi was found in leaves of grapevines inoculated with $R$. clarus (Fig. 2e). The increase in leaf Pi concentration stimulates photophosphorylation and ATPase activity, which otherwise would be inhibited, thus causing a decrease in plant photosynthetic rate (Paul and Pellny, 2003). Part of the P absorbed by the grapevines was most likely transported to shoots in the form of phosphate, which in the 

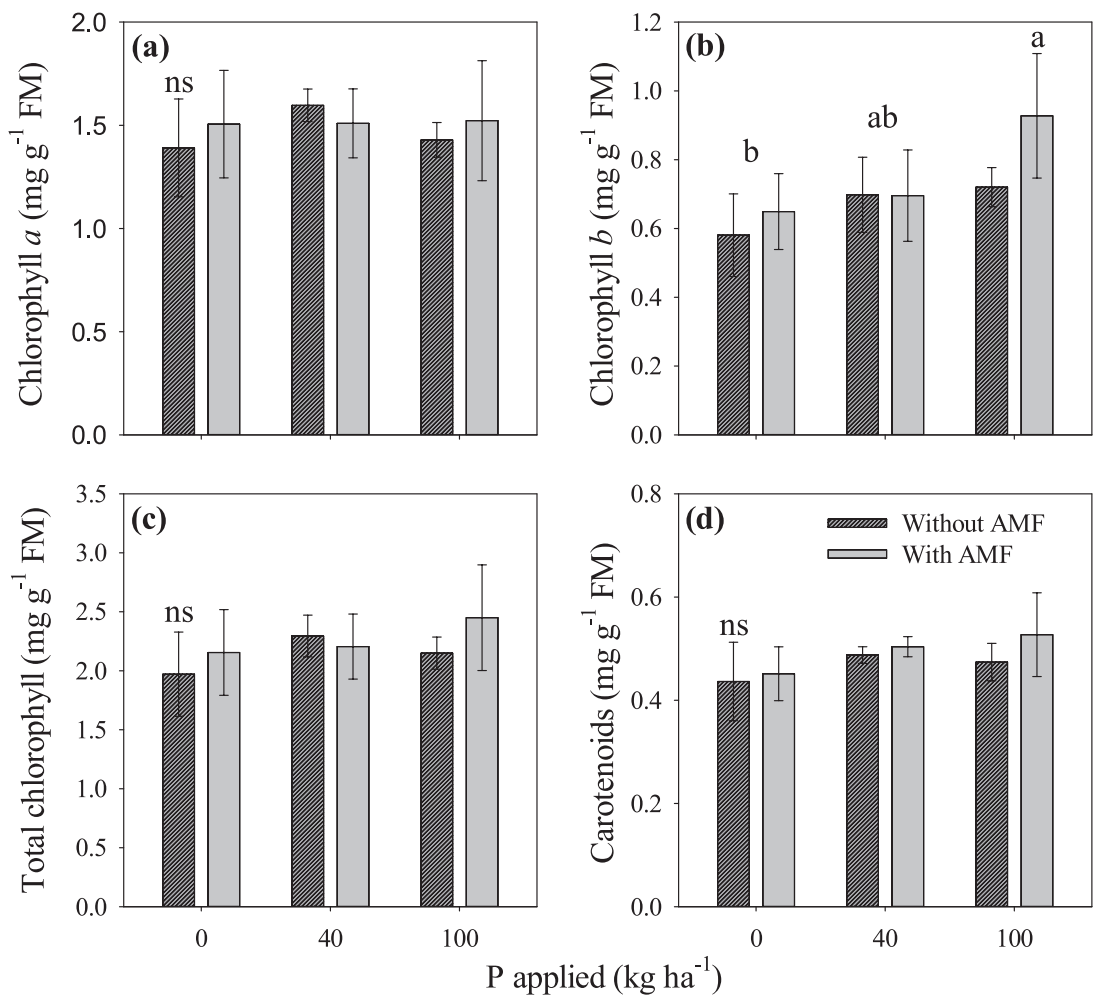

Fig. 4. Chlorophyll $a$ (a), chlorophyll $b$ (b), total chlorophyll (c) and carotenoids (d) in leaves of young grapevines grown in soil with high $\mathrm{Cu}$ content subjected to $\mathrm{P}$ applied, with and without inoculation with $R$. clarus. The vertical bars in each column represent the standard deviation of the mean. Same uppercase letters compare treatments with and without inoculation with $R$. clarus, and lowercase letters compare P applied. Means followed by the same letters do not differ the treatments by the Tukey test $(\mathrm{p}<0.05)$. ns $=$ not significant. tissue is a component of compounds like phosphate sugars (including glucose and fructose), membrane phospholipids, adenosine triphosphate (ATP) and nucleic acids (Marschner, 2012). In addition to this, $P$ is an important photosynthesis regulator, thorough reduce carbon loading and unloading (i.e. sucrose and starch) as well as amino acids synthesis (Paul and Pellny, 2003).

Most of the absorbed $\mathrm{Cu}$ was accumulated in roots. These results are consistent to those found for grapevine grown in Cu-contaminated soils (Tiecher et al., 2017) and those grown in nutrient solution with high $\mathrm{Cu}$ concentration (Cambrollé et al., 2013, 2015). This shows that the root system of grapevines has mechanisms that may prevent and/or reduce excess $\mathrm{Cu}$ translocation to shoots. This may be associated to the low mobility of $\mathrm{Cu}$ in plants, because it has strong interaction with protein nitrogen (N) (Kabata-Pendias, 2011). Moreover, Cu has strong interaction with the sulfhydryl groups of enzymes and proteins in the apoplast of root cells and, may inhibit enzyme activity or cause changes in structure and replacement of key elements, resulting in deficiency of other nutrients (Yruela, 2005; Kabała et al., 2008). For this reason, shoot $\mathrm{Cu}$ contents were lower, in levels considered normal for most plants (5-30 $\mathrm{mg} \mathrm{kg}^{-1}$ ) (Kabata-Pendias, 2011), preventing severe damage to plant metabolism.

The increase of $\mathrm{P}$ in plant tissue may also have contributed to the occurrence of shoot $\mathrm{Cu}$ contents considered normal, even when plants exhibited high $\mathrm{Cu}$ concentrations in roots. The increase in tissue $\mathrm{P}$ may decrease the transport of heavy metals such as $\mathrm{Cu}$ from root to shoot, because it allows phosphate binding with free metal ions within the cells. The efficiency of $\mathrm{P}$ in decreasing the transport of heavy metals to shoots was previously observed by Soares and Siqueira (2008) in Brachiaria decumbens Stapf. subjected to high levels of $\mathrm{Cu}$, zinc ( $\mathrm{Zn}$ ) and cadmium (Cd). Moreover, higher shoot $\mathrm{P}$ content also allows binding with metal ions (such as free $\mathrm{Cu}$ in the cells), thus reducing the toxic effects caused by excess Cu (Barceló and Poschenrieder, 1992).

Inoculation also influenced $\mathrm{Cu}$ uptake by the young grapevines. At the dose of $40 \mathrm{mg} \mathrm{P} \mathrm{kg}^{-1}$, the ratio of $\mathrm{Cu}$ concentrations in roots and shoots $(\mathrm{R} / \mathrm{S})$ was 21:1 for inoculated and 10:1 non-inoculated plants, respectively. This result shows the ability of $R$. clarus to restrict the transport of excessive amounts of $\mathrm{Cu}$ to shoots, which is another strategy for protecting grapevines to $\mathrm{Cu}$ toxicity. Among the mechanisms mediated by AMF in reducing the transport of phytotoxic elements in plants is the production and release of glomalin in soil, which is able to reduce $\mathrm{Cu}$ availability because of its high reactivity (Folli-Pereira et al., 2012). Additionally, it retains $\mathrm{Cu}$ in the fungal mycelium or in spores, thus reducing uptake by mycorrhizal plants (Cornejo et al., 2013).

The addition of $\mathrm{P}$ and AMF inoculation did not affect maximum quantum yield (Fv/Fm) in plants. This may be attributed to higher root $\mathrm{Cu}$ content and normal shoot $\mathrm{Cu}$ content. Therefore, the grapevines did not show drastic changes in leaf metabolic processes and did not compromise the efficiency of the photosynthetic apparatus (Freitas et al., 2015). On the other hand, there was increased electron transport rate (ETR) in inoculated plants and increased maximum quantum yield of the PSII (Y(II)) in plants treated with P. These responses may be related to increased $\mathrm{P}$ sorption as a result of the symbiosis with AMF (Soares and Siqueira, 2008) and the higher P availability due to application in soil, which improved plant photosynthesis. However, the reduction of $\mathrm{Y}(\mathrm{II})$ in plants not treated with $\mathrm{P}$ characterizes a state of photoinhibition (Alves et al., 2002). For this reason, a smaller amount of the energy captured by the plant through complex antenna is used to reduce carbon and produce dry matter.

Plants grown in environments with high concentrations of heavy metals typically have reduced contents of chlorophyll $a$, chlorophyll $b$ and carotenoids (Cambrollé et al., 2015; Tiecher et al., 2017, 2018). This reduction may be related to $\mathrm{Cu}$ translocation to shoots (e.g., leaves), where it could replace $\mathrm{Mg}$ in the chlorophyll molecule, impairing photosynthesis (Yruela, 2009). Furthermore, excess Cu may cause degradation of the structure and internal content of the chloroplast (Ciscato et al., 1997), resulting reduced content of photosynthetic pigments and, consequently, energy uptake by plants.

The increase in chlorophyll $b$ content observed in plants treated with $\mathrm{P}$ may be related to improved plant nutritional status caused by $\mathrm{P}$ addition and, reflects a condition of lower stress. Chlorophyll $b$ is highly concentrated in the antenna complex (Pearcy and Yang, 1998) and absorbs light energy at a shorter, hence more energetic wavelength than chlorophyll $a$. Thus, increasing the concentration of chlorophyll $b$ 
is an effective way to increase the energy that reaches PSII, resulting in increased energy capture and excitation state of chlorophyll, increasing carbon reduction through photosynthesis.

Reactive oxygen species (ROS) such as $\mathrm{H}_{2} \mathrm{O}_{2}$ and $\mathrm{OH}^{-}$and $\mathrm{O}_{2}{ }^{-}$ radicals are formed naturally within cells, especially in chloroplasts and mitochondria (Ferreira et al., 2015), as a result of electron transport and cellular respiration, respectively. However, the production of ROS is drastically increased under conditions of toxicity, as in high levels of $\mathrm{Cu}$ in soil; through reaction with other molecules, causing lipid peroxidation and decreased membrane-bound enzyme activity (Del Río et al., 2006). The activation of enzymatic antioxidant system under ROS formation is a common strategy used by plants exposed to $\mathrm{Cu}$ excess (Gill and Tuteja, 2010). Still in this view, superoxide dismutase (SOD) activity, which is part of the primary defense system of plants for the elimination of $\mathrm{O}_{2}{ }^{-}$radicals is often reported (Girotto et al., 2013; Tiecher et al., 2017). In this study, we did not observe any change in SOD activity in plants treated with $\mathrm{P}$. This suggests that $\mathrm{O}_{2}{ }^{-}$that is being produced is predominantly degraded in the cell, without oxidative stress in the cells of young grapevines. Additionally, there was a tendency of higher activity without AMF inoculation as compared with no inoculate plants.

\section{Conclusions}

Phosphorus fertilization and inoculation of $R$. clarus (AMF) are potential strategies to reduce $\mathrm{Cu}$ toxicity in young grapevines. Improving plant nutritional status via $\mathrm{P}$ fertilization or AMF inoculation promotes plant growth and reduces $\mathrm{Cu}$ transport from roots to shoots. Furthermore, AMF inoculation also protects the photosynthetic apparatus of the grapevine due to the increased quantum yield of PSII.

\section{Acknowledgments}

We would like to thank the Coordenação de Aperfeiçoamento de Pessoal de Nível Superior (Capes) and the Conselho Nacional de Desenvolvimento Científico e Tecnológico (CNPq) for the financial support.

\section{References}

Alves, P.L., Magalhães, A.C.N., Barja, P.R., 2002. The phenomenon of photoinhibition of photosynthesis and its importance in reforestation. Bot. Rev. 68, 193-208.

Ambrosini, V.G., Rosa, D.J., Prado, J.P.C., Borghezan, M., Melo, G.W.B., Soares, C.R.F.S., Comin, J.J., Simão, D.G., Brunetto, G., 2015. Reduction of copper phytotoxicity by liming: A study of the root anatomy of young vines (Vitis labrusca L.). Plant Physiol. Biochem. 96, 270-280.

Azevedo, R.A., Alas, R.M., Smith, R.J., Lea, P.J., 1998. Response of antioxidant enzymes to transfer from elevated carbon dioxide to air and ozone fumigation in the leaves and roots of wild-type and catalase-deficient mutant of barley. Physiol. Plant. 104, 280-292.

Barceló, J., Poschenrieder, C., 1992. Respuestas de las plantas a la contaminacion por metales pesados. Suelo Planta 2, 345-361.

Barrow, N.J., 1999. The four laws of soil chemistry: The Leeper lecture. 1998. Aust. J. Soil Res. 37, 787-829.

Bradford, M.M., 1976. A rapid and sensitive method for the quantitation of microgram quantities of protein utilizing the principle of protein-dye binding. Plant Physiol. Biochem. 72, 248-254.

Brunetto, G., Lorensini, F., Ceretta, C.A., Gatiboni, L.C., Trentin, G., Girotto, E., Miotto, A., Lourenzi, C.R., Melo, G.W., 2013. Soil phosphorus fractions in a sandy TypicHapludaft as affected by phosphorus fertilization and grapevine cultivation period. Commun. Soil Sci. Plant Anal. 44, 937-1950.

Brunetto, G., Melo, G.W.B., Terzano, R., Del Buono, D., Astolfi, S., Tomasi, N., Pii, Y., Mimmo, T., Cesco, S., 2016. Copper accumulation in vineyard soils: rhizosphere processes and agronomic practices to limit its toxicity. Chemosphere 162, 293-307.

Cabral, L., Soares, C.R.F.S., Giachini, A.J., Siqueira, J.A., 2015. Arbuscular mycorrhizal fungi in phytoremediation of contaminated areas by trace elements: mechanisms and major benefits of their applications. World J. Microbiol. Biotechnol. 31, 1655-1664.

Cambrollé, J., García, J.L., Ocete, R., Figueroa, M.E., Cantos, M., 2013. Growth and photosynthetic responses to copper in wild grapevine. Chemosphere 93, 294-301.

Cambrollé, J., García, J.L., Figueroa, M.E., Cantos, M., 2015. Evaluating wild grapevine tolerance to copper toxicity. Chemosphere 120, 171-178.

Cao, R.X., Lena, L.Q., Chen, M., Singh, S.P., Harris, W.G., 2003. Phosphate induced metal immobilization in a contaminated site. Environ. Pollut. 122, 19-28.
Chan, K., Delfret, D., Junges, K., 1986. A direct colorimetric assay for $\mathrm{Ca}^{2+}$-ATPase activity. Anal. Biochem. 157, 375-380.

Ciscato, M., Valcke, R., van Loven, K., Clijsters, H., Navari-Izzo, F., 1997. Effects of in vivo copper treatment on the photosynthetic apparatus of two Triticum durum cultivars with different stress sensitivity. Physiol. Plant. 100, 901-908.

Cornejo, P., Pérez-Tienda, J., Meier, S., Valderas, A., Borie, F., Azcón-Aguilar, C., Ferrol, N., 2013. Copper compartmentalization in spores as a survival strategy of arbuscular mycorrhizal fungi in Cu-polluted environments. Soil Biol. Biochem. 57, 925-928.

CQFS-RS/SC, 2016. Comissão de Química e Fertilidade do Solo - RS/SC. Manual de calagem e adubação para os Estados do Rio Grande do Sul e de Santa Catarina. Sociedade Brasileira de Ciência do Solo 376p.

Del Río, L.A., Sandalio, L.M., Corpas, F.J., Palma, J.M., Barroso, J.B., 2006. Reactive oxygen species and reactive nitrogen species in peroxisomes: production, scavenging, and role in cell signaling. Physiol. Plant. 141, 330-335.

Farias, J.G., Antes, F.L.G., Nunes, P.A.A., Nunes, S.T., Schaich, G., Rossato, L.V., Miotto, A., Girotto, E., Tiecher, T.L., Dressler, V.L., Nicoloso, F.T., 2013. Effects of excess copper in vineyard soils on the mineral nutrition of potato genotypes. Food Energy Secur. 2 (1), 49-69.

Ferreira, P.A.A., Ceretta, C.A., Soriani, H.H., Tiecher, T.L., Soares, C.R.F.S., Rossato, L.V., Nicoloso, F.T., Brunetto, G., Paranhos, J.T., Cornejo, P., 2015. Rhizophagus clarus and phosphate alter the physiological responses of Crotalaria juncea cultivated in soil with a high Cu level. Appl. Soil Ecol. 91, 37-47.

Ferreira, P.A.A., Tiecher, T., Tiecher, T.L., Rangel, W.M., Soares, C.R.F.S., Deuner, S., Tarouco, C.P., Giachini, A.J., Nicoloso, F.T., Brunetto, G., Coronas, M.V., Ceretta, C.A., 2018. Effects of Rhizophagus clarus and P availability in the tolerance and physiological response of Mucuna cinereum to copper. Plant Physiol. Biochem. 122, 46-56.

Folli-Pereira, M.S., Meira-Haddad, L.S., Bazzolli, D.M.S., Kasuya, M.C.M., 2012. Micorriza arbuscular e a tolerância das plantas ao estresse. R. Bras. Ci. Solo 36, 1663-1679.

Freitas, T.A., França, M.G.C., Almeida, A.F., Oliveira, S.J.R., Jesus, R.M., Souza, V.L., Silva, J.V.S., Mangabeira, P.A., 2015. Morphology, ultrastructure and mineral uptake is affected by copper toxicity in young plants of Inga subnudasubs.luschnathiana (Benth.) T.D. Penn. Environ. Sci. Pollut. R. 22, 15479-15494.

Gerdemann, J.W., Nicolson, T.H., 1963. Spores of micorrhizal endogene species extracted from soil by wet sieving and decanting. Trans. Brit. Mycol. Soc. 75, 235-244.

Giannopolitis, C.N., Ries, S.K., 1977. Superoxide dismutase I. Occurrence in higher lants. Plant Physiol. 59, 309-314.

Gill, S.S., Tuteja, N., 2010. Reactive oxygen species and antioxidant machinery in abiotic stress tolerance in crop plants. Plant Physiol. Biochem. 48, 909-930.

Giovannetti, M., Mosse, B., 1980. An evaluation of techniques for measuring vesicular arbuscular mycorrhizal infection in roots. New Phytologist, Oxford. 84, 489-500.

Girotto, E., Ceretta, C.A., Rossato, L.V., Farias, J.G., Tiecher, T.L., De Conti, L., Schmatz, R., Brunetto, G., Schetinger, M.R.C., Nicoloso, F.T., 2013. Triggered antioxidant defense mechanism in maize grown in soil with accumulation of $\mathrm{Cu}$ and $\mathrm{Zn}$ due to intensive application of pig slurry. Ecotox. Environ. Safe. 93, 145-155.

Gupta, M., Bisht, S., Singh, S., Gulati, A., Tewari, R., 2014. Enhanced biomass and steviol glycosides in Stevia rebaudiana treated with phosphate-solubilizing bacteria and rock phosphate. Plant Growth Regul. 65, 447-449.

Methods in comparative plant ecology. In: Hendry, G.A.F., Grime, J.P. (Eds.), A Laboratory Manual. Chapman \& Hall, London, pp. 148-152.

Janicka-Russak, M., Kabała, K., Burzyński, M., Kłobus, G., 2008. Response of plasma membrane $\mathrm{H}^{+}$-ATPase to heavy metal stress in Cucumissativus roots. J. Exp. Bot. 59, 3721-3728.

Kabała, K., Janicka-Russak, M., Burzynski, M., Kłobus, G., 2008. Comparison of heavy metal effect on the proton pumps of plasma membrane and tonoplast in cucumber root cells. J. Plant Physiol. 165, 278-288.

Kabata-Pendias, A., 2011. Trace Elements in Soils and Plants. CRC Press, Boca Ratón, Florida.

Koske, R.E., Gemma, J.N., 1989. A modified procedure for staining roots to detect VA mycorrhiza. Mycol. Res. 92, 486-505.

Lichtenthaler, H.K., 1987. Chlorophylls and carotenoids: pigments of photosynthetic biomembranes. Method Enzymol. 148, 350-382.

Marschner, P., 2012. Mineral Nutrition of Higher Plants, 3nd ed. Academic Press, London p.

McBride, Murray B., 1994. Environmental Chemistry of Soils. Oxford University Press, New York.

Meyer, S.T., Castro, S.R., Fernandes, M.M., Soares, A.C., Souza Freitas, G.A., Ribeiro, E., 2016. Heavy-metal contaminated industrial soil: Uptake assessment in native plant species from Brazilian Cerrado. Int. J. Phytoremediation 18, 832-838.

Paul, M.J., Pellny, T.K., 2003. Carbon metabolite feedback regulation of leaf photosynthesis and development. J. Exp. Bot. 5, 539-547.

Pearcy, R.W., Yang, W., 1998. The functional morphology of light capture and carbon gain in Redwood forest understorey plant Adenocaulon bicolor (Hook.). Funct. Ecol. $12,543-552$.

Pérez-Novo, C., Bermúdez-Couso, A., López-Periago, E., Fernández-Calviño, D., Arias Estévez, M., 2009. The effect of phosphate on the sorption of copper by acid soils. Geoderma 150, 166-170.

Rosa, D.J., Ambrosini, V.G., Brunetto, G., Soares, C.R.F.S., Borghezan, M., Pescador, R., 2016. Parâmetros fisiológicos em videiras 'Paulsen 1103' (Vitis berlandieri x Vitis rupestris) inoculadas com fungos micorrízicos arbusculares em solo contaminado com cobre. Ciência Téc. Vitiv. 31, 14-23.

Sarruge, J.R., Haag, H.P., 1974. Análise química das plantas. ESALQ, Piracicaba 56 p.

Soares, C.R.F.S., Siqueira, J.O., 2008. Mycorrhiza and phosphate protection of tropica grass species against heavy metal toxicity in multi-contaminated soil. Biol. Fertil. Soils 44, 833-841.

Soil Survey Staff, 2006. Soil Taxonomy: a Basic System of Soil Classification for Making 
and Interpreting Soil Surveys, 2nd ed. US Government Printing Office, Washington DC.

Tabaldi, L.A., Ruppenthal, R., Cargnelutti, D., Morsch, V.M., Pereira, L.B., Schetinger, M.R.C., 2007. Effects of metal elements on acid phosphatase activity in cucumber (Cucumis sativus L.) seedlings. Environ. Exp. Bot. 59, 43-48.

Tiecher, T.L., Tiecher, T., Ceretta, C.A., Ferreira, P.A.A., Nicoloso, F.T., Soriani, H.H., De Conti, L., Kulmann, M.S.S., Schneider, R.O., Brunetto, G., 2017. Tolerance and translocation of heavy metals in young grapevine (Vitis vinifera) grown in sandy acidic soil with interaction of high doses of copper and zinc. Sci. Hortic. 222, 203-212.

Tiecher, T.L., Soriani, H.H., Tiecher, T., Ceretta, C.A., Nicoloso, F.T., Tarouco, C.P., Clasen, B.E., De Conti, L., Tassinari, A., Melo, G.W.B., Brunetto, G., 2018. The interaction of high copper and zinc doses in acid soil changes the physiological state and development of the root system in young grapevines (Vitis vinifera). Ecotox. Environ. Safe. 148, 985-994.

Trouvelot, S., Bonneau, L., Redecker, D., Tuinen, D.V., Adrian, M., Wipf, D., 2015. Arbuscular mycorrhiza symbiosis in viticulture: a review. Agron. Sustain. Dev. 35, 1449-1467.

Yang, Y., Sun, C., Yao, Y., Zhang, Y., Achal, V., 2011. Growth and physiological responses of grape (Vitis vinifera "Combier") to excess zinc. Acta Physiol. Plant. 33, 1483-1491. Yruela, I., 2005. Copper in plants. Braz. J. Plant Physiol. 171, 145-156.

Yruela, I., 2009. Copper in plants: acquisition, transport and interactions. Funct. Plant Biol. 36 (5), 409-430. 